\title{
Effect of the North Atlantic Oscillation on the Thermal Characteristics of Lakes in Poland
}

\author{
Dariusz WRZESIŃSKI, Adam CHOIŃSKI, and Mariusz PTAK
}

Institute of Physical Geography and Environmental Planning,

Adam Mickiewicz University, Poznań, Poland; e-mails: darwrze@amu.edu.pl, choinski@amu.edu.pl, marp114@wp.pl (corresponding author)

\begin{abstract}
This paper presents the effect of the North Atlantic Oscillation (NAO) on the thermal characteristics of lakes in Poland. In the analysis, the use was made of monthly air temperatures recorded at fifteen meteorological stations, water temperatures of twelve lakes, and Hurrell's winter NAO indices. Over the study period (1971-2010), there was a marked increase in the temperatures of both, air and lake waters. Depending on the NAO phase, water temperatures were observed to depart from mean values, being markedly higher than average (even by $1^{\circ} \mathrm{C}$ ) in the positive winter NAO phase. The differences in water temperatures were statistically significant in the winter-spring season. In turn, in the negative $\mathrm{NAO}_{\text {DJFM }}$ phase lake water temperatures in winter and spring were markedly lower than average (in March even by $1.0^{\circ} \mathrm{C}$ ). The unique response of some lakes depends on their morphometric parameters, including their mean depth.
\end{abstract}

Key words: global warming, climate change, water temperature, macroscale atmospheric circulation.

\section{INTRODUCTION}

The pattern of processes and phenomena occurring in lakes results from global range-factors (air circulation, radiation level), local conditions in their

Ownership: Institute of Geophysics, Polish Academy of Sciences;

(C) 2015 Wrzesiński et al. This is an open access article distributed under the Creative Commons Attribution-NonCommercial-NoDerivs license,

http://creativecommons.org/licenses/by-nc-nd/3.0/. 
catchments (use pattern, hypsometry, etc.), and their individual morphometric parameters (area, depth, etc.). Of fundamental importance are the first ones, but what make even neighbouring water bodies different are their morphometric characteristics. Thus, in order to establish regularities controlling the functioning of a lake ecosystem, it is necessary to identify all the factors listed, both global ones and those unique to individual lakes.

In the case of Europe, hydrometeorological conditions are heavily influenced by one of the macro-scale types of circulation, viz. the North Atlantic Oscillation (NAO). It is a bi-polar type of circulation with centres located over Iceland and the Azores. The period in which the difference in pressure between the Azores High and the Icelandic Low is big is termed a positive NAO phase, or mode. This generates strong winds over Europe from the south-west and the transport of humid and warm air masses, mainly to the northern regions of the continent. A negative NAO phase is characterised by a clearly weaker Icelandic low and a shallower Azores High. The air masses that flow to Europe are then dry and cool and come from the north-east. As a result, precipitation is lower in northern Europe and markedly higher on the Iberian Peninsula. The NAO affects climatic conditions the strongest in winter, but also in the other seasons high values of its index are accompanied by higher-than-average air temperatures in western Europe (Carleton 1988, Rogers 1997, Trigo et al. 2002). It also determines climatic conditions in Poland by causing an increase in temperature in the cold season of the year (Marsz and Styszyńska 2001, Przybylak et al. 2003) and influencing radiation and humidity conditions (Bryś and Bryś 2002), precipitation (Styszyńska 2001, Wibig 2001), as well as the duration and thickness of snow cover (Falarz 2007). With reference to lakes, the NAO's effect is visible in their patterns of thermal conditions and ice phenomena. The NAOrelated rise in the temperature of lake waters (Livingstone and Dokulil 2001, Straile et al. 2003, Gerten and Adrian 2002) has such consequences as, e.g., an earlier disappearance of ice cover in the years with a positive winter NAO index (D'Odorico et al. 2002, Wrzesiński et al. 2013). In turn, changes in the heat balance of lakes brought about by the NAO transform the conditions of biological life in those ecosystems (Straile and Adrian 2000, Ottersen et al. 2001).

The principal goal of this paper is to compare the range of changes in the water temperature of the lakes under study in the individual winter NAO phases with the average values, as well as their spatial and temporal patterns. An attempt is also made to account for the observed differences in terms of both, a global factor in the form of changes in air temperature as well as local factors and morphometric features of the lakes. Thus, the authors seek to explain whether macro-scale factors controlling the thermal conditions of the lakes are modified by their individual features, and if so, to what extent. 


\section{MATERIAL AND METHODS}

In the research use was made of standard measurements of lake water temperature at a depth of $0.4 \mathrm{~m}$ performed once a day at 7:00 (GMT +1) over the 40-year study period by the Institute of Meteorology and Water Management. Owing to frequent reorganisations of the observation network, the longest observation series cover a relatively small number of lakes, their greater density being found in the north-eastern part of Poland (the Mazurian Lakeland). However, since the distribution of a decided majority of Polish lakes is a product of the Last Pleistocene Glaciation (which embraced the north of the country), the bodies found in this location can be regarded as representative of the lakes in Poland. Also used were air temperature data (monthly means) from fifteen stations found in Internet climatic databases (http://www7.ncdc.noaa.gov/CDO/dataproduct, www.tutiempo.net). The morphometric characteristics of the lakes are presented in Table 1, while their location and that of the meteorological stations is given in Fig. 1.

In this paper use was made of the winter NAO index $\left(\mathrm{NAO}_{\text {DJFM }}\right)$ worked out by Hurrell (1995; http://www.cgd.ucar.edu/cas/jhurrell/nao.stat.winter. $\mathrm{html}$ ). It is a normalised mean difference in atmospheric pressure in the December-March period (DJFM) between Lisbon at one end of the continent and Stykkisholmur and Reykjavik at the other. The term "a positive NAO phase" $(\mathrm{NAO}+)$ should be understood as the years in which the difference in pressure between the Azores High and the Icelandic Low is big, and the

Table 1

Morphometric data of the studied lakes (after Choiński 2006)

\begin{tabular}{|c|l|r|r|c|c|l|}
\hline No. & \multicolumn{1}{|c|}{ Lake } & $\begin{array}{c}\text { Area } \\
{[\mathrm{ha}]}\end{array}$ & $\begin{array}{c}\text { Volume } \\
\left.\text { [thous. } \mathrm{m}^{3}\right]\end{array}$ & $\begin{array}{c}\text { Depth } \\
\text { average [m] }\end{array}$ & $\begin{array}{c}\text { Altitude } \\
{[\mathrm{m} \text { a.s.1.] }}\end{array}$ & Mictic type \\
\hline 1 & Charzykowskie & 1336 & 134533.2 & 9.8 & 120 & stratified \\
3 & Gardno & 2337.5 & 30950.5 & 1.3 & 0.3 & unstratified \\
4 & Hańcza & 291.5 & 120364.1 & 38.7 & 227.3 & stratified \\
5 & Jamno & 2231.5 & 31528 & 1.4 & 0.1 & unstratified \\
6 & Lubiorak & 3152.5 & 141594.2 & 4.1 & 99.2 & stratified \\
7 & Lebsko & 1487.5 & 169880.5 & 11.6 & 95.4 & stratified \\
8 & Mikołajskie & 4080 & 117521 & 1.6 & 0.2 & unstratified \\
9 & Selmęt Wielki & 1207.5 & 99463.9 & 7.8 & 120.7 & stratified \\
10 & Sępoleńskie & 157.5 & 7501.6 & 4.8 & 112.8 & stratified \\
11 & Sławskie & 822.5 & 42664.8 & 5.2 & 56.9 & stratified \\
12 & Studzieniczne & 244 & 22073.6 & 8.7 & 123.4 & stratified \\
\hline
\end{tabular}




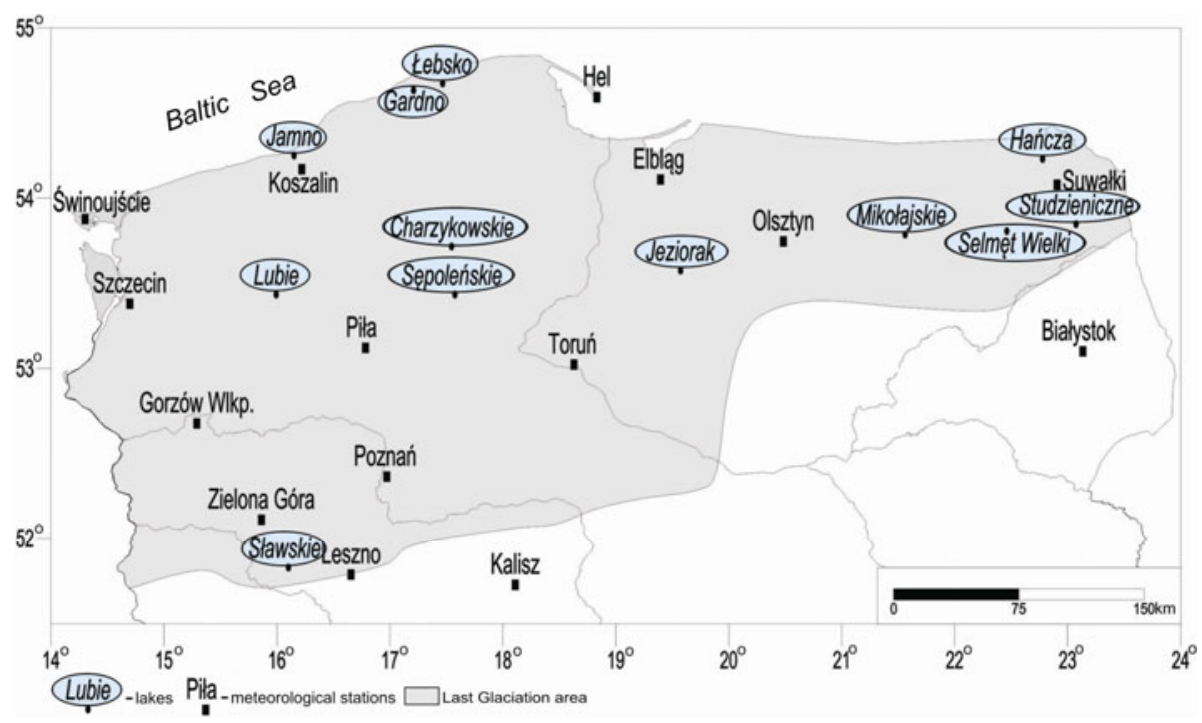

Fig. 1. Location of the limnological and meteorological stations.

$\mathrm{NAO}_{\text {DJFM }}$ index values exceed 2.52. In turn, a negative NAO phase (NAO-) means the years in which the Icelandic Low is clearly weaker, the Azores High shallower, and the $\mathrm{NAO}_{\text {DJFM }}$ values under -0.63 . Those values roughly correspond to the first and third quartiles from the entire set of $\mathrm{NAO}_{\mathrm{DJFM}}$ indices for the years 1971-2010.

To determine the relationship between changes in the temperature of lake water and the intensity of the North Atlantic Oscillation, Pearson's coefficient of linear correlation $(r)$ was calculated, the correlation holding between the monthly, seasonal, and annual water temperatures on the one hand and Hurrell's winter $\mathrm{NAO}_{\text {DJFM }}$ index on the other. Changes in the thermal characteristics of the lakes in the two $\mathrm{NAO}_{\text {DJFM }}$ modes were established on the basis of differences in water temperatures in the positive and the negative mode against means from the years 1971-2010. Average monthly, seasonal and annual temperatures were calculated for years with high $(\mathrm{NAO}+)$ and low (NAO-) values of the winter NAO index. The statistical significance of those differences was examined using the $T$-test for independent samples. The hypothesis tested each time was $H_{0}: \mu_{1}=\mu_{2}$ about the equality of expected values against $H_{1}: \mu_{1} \neq \mu_{2}$. The rejection of the hypothesis allows the conclusion that there are significant differences between the mean temperatures observed in the various $\mathrm{NAO}_{\mathrm{DJFM}}$ phases and the average magnitudes. The $T$-statistic has Student's distribution, with $n_{1}+n_{2}-2$ degrees of freedom: 


$$
T=\frac{\overline{X_{1}}-\overline{X_{2}}}{S_{\overline{X_{1}}-\overline{X_{2}}}}
$$

where $S_{\overline{X_{1}}-\overline{X_{2}}}$ equals

$$
S_{\overline{X_{1}}-\overline{X_{2}}}=\sqrt{\frac{\left(n_{1}-1\right) S_{1}^{2}+\left(n_{2}-1\right) S_{2}^{2}}{n_{1}+n_{2}-2}\left(\frac{1}{n_{1}}+\frac{1}{n_{2}}\right)},
$$

where $n_{1}$ and $n_{2}$ are the sample sizes, $S_{1}^{2}$ and $S_{2}^{2}$ are the sample variances, and $\overline{X_{1}}-\overline{X_{2}}$ are the sample means.

Spatial differences in the observed temperature changes are presented in a tabular and a graphic form. The graphics was prepared using the Surfer 10 program (GoldenSoftware), and in the construction of isoline maps the kriging procedure was employed.

\section{RESULTS AND DISCUSSION}

\subsection{Preliminary results}

The distribution of air temperatures obtained in the study period (1971-2010) for the fifteen weather stations shows annual means to decrease from west to east, which is connected with a stronger impact of the continental climate in the east of Poland, as observed by Ewert (1973). The highest mean annual air temperature was recorded in Szczecin $\left(8.95^{\circ} \mathrm{C}\right)$ and Zielona Góra $\left(8.81^{\circ} \mathrm{C}\right)$, and the lowest in Suwałki $\left(6.57^{\circ} \mathrm{C}\right)$ and Białystok $\left(7.10^{\circ} \mathrm{C}\right)$. At all the stations the mean annual air temperature can be observed to be rising. The increase was the highest in Gorzów Wielkopolski, Koszalin, and Piła, at $0.37^{\circ} \mathrm{C}$ per decade. In the annual cycle, the steepest rise in temperature can be noted in April, in Zielona Góra and Gorzów, by $0.96^{\circ} \mathrm{C}$ and $0.93^{\circ} \mathrm{C}$, respectively.

Also mean annual temperatures of lake waters calculated for the same period were different. The highest values were recorded in Lake Sławskie $\left(10.8^{\circ} \mathrm{C}\right)$, and the lowest in Lake Hańcza $\left(8.5^{\circ} \mathrm{C}\right)$. The differences in their monthly temperatures were the widest in spring months: in April and May the water in Lake Sławskie was by more than $5.1{ }^{\circ} \mathrm{C}$ warmer than in Hańcza.

Over the multi-year period under study, the mean annual water temperatures displayed an upward tendency in all the lakes. The highest increases per decade were recorded for lakes Lubie $\left(0.55^{\circ} \mathrm{C}\right)$ and Selmęt Wielki $\left(0.43^{\circ} \mathrm{C}\right)$, and the lowest for Jamno $\left(0.25^{\circ} \mathrm{C}\right)$ and Hańcza $\left(0.26^{\circ} \mathrm{C}\right)$. In the annual cycle, the warming of lake waters is especially readily visible in spring (April, May) and summer (July, August). The highest rises in the mean monthly water temperatures per decade were noted for lakes Lubie (in 
May by $1.02^{\circ} \mathrm{C}$, in July by $0.76^{\circ} \mathrm{C}$, and in April by $0.73^{\circ} \mathrm{C}$ ), Sławskie (in May by $0.79^{\circ} \mathrm{C}$ ), and Selmęt Wielki (in April by $0.70^{\circ} \mathrm{C}$ ). These results support the observations of changes in the thermal characteristics of lakes in Poland made so far. When analysing changes in the temperatures of surface water of lakes in the period 1961-2005, Skowron (2011) found them to show an upward tendency (on average, by $0.2^{\circ} \mathrm{C}$ per decade). The steepest increase was observed between March and May $\left(0.02-0.05^{\circ} \mathrm{C}\right.$ per year).

\subsection{NAO - T-test correlation}

In this paper correlations were examined of monthly, seasonal, and annual water and air temperatures with the winter NAO index $\left(\mathrm{NAO}_{\mathrm{DJFM}}\right)$. The results obtained corroborate earlier findings, both in the case of polymictic lakes (Girjatowcz 2011) and those displaying summer stratification (Livingstone 1993, Gerten and Adrian 2001).

The strongest effect of the North Atlantic Oscillation on the thermal characteristics of lake waters can be observed in winter and spring months (from January to April). The calculated correlation coefficients are high and statistically significant $(p<0.05)$. Similar results were obtained for mean temperatures of lake waters in the winter and spring seasons. Only two lakes, Hańcza and Lubie, showed no significant correlation with the NAO $\mathrm{DJFM}_{\text {in- }}$ dex. There was a less statistically significant correlation between annual

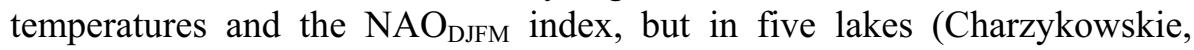
Gardno, Jeziorak, Łebsko, and Sępoleńskie) the correlation coefficient was significant at $p=0.05$ (Table 2). Even stronger correlations were observed between air temperatures and $\mathrm{NAO}_{\mathrm{DJFM}}($ Table 3 ).

In the next stage of the research, it was established how the temperatures of lake waters and air in years with high and low values of the NAO DJFM index departed from average values (Tables 4-7). Spatial differences in changes in the temperature of air and lake waters in the winter-spring period (January-April) under the influence of NAO and for the entire year are presented in Figs. 2 and 3.

Lake water temperatures grow markedly in the positive $\mathrm{NAO}_{\text {DJFM }}$ phase and go down in the negative one, especially in the period of the strongest impact of the North Atlantic Oscillation, i.e., in winter and spring. In the positive $\mathrm{NAO}_{\text {DJFM }}$ phase in those periods, water temperatures are distinctly higher than average. The most statistically significant differences in water temperatures occur from January to March (an increase from $0.6^{\circ} \mathrm{C}$ to $1{ }^{\circ} \mathrm{C}$, $p<0.05$ ) in lakes situated in the central, longitudinal belt of the study area. The differences decrease both, to the west (the smallest increase in temperature in the positive the NAO phase, $0.2-0.3^{\circ} \mathrm{C}$, observed in Lake Lubie), and to the east (in Lakes Hańcza, $0.1{ }^{\circ} \mathrm{C}$, and Studzieniczne, $0.3^{\circ} \mathrm{C}$ ). In April the differences are also high, from $0.6^{\circ} \mathrm{C}$ in the central part to $1{ }^{\circ} \mathrm{C}$ in the east 


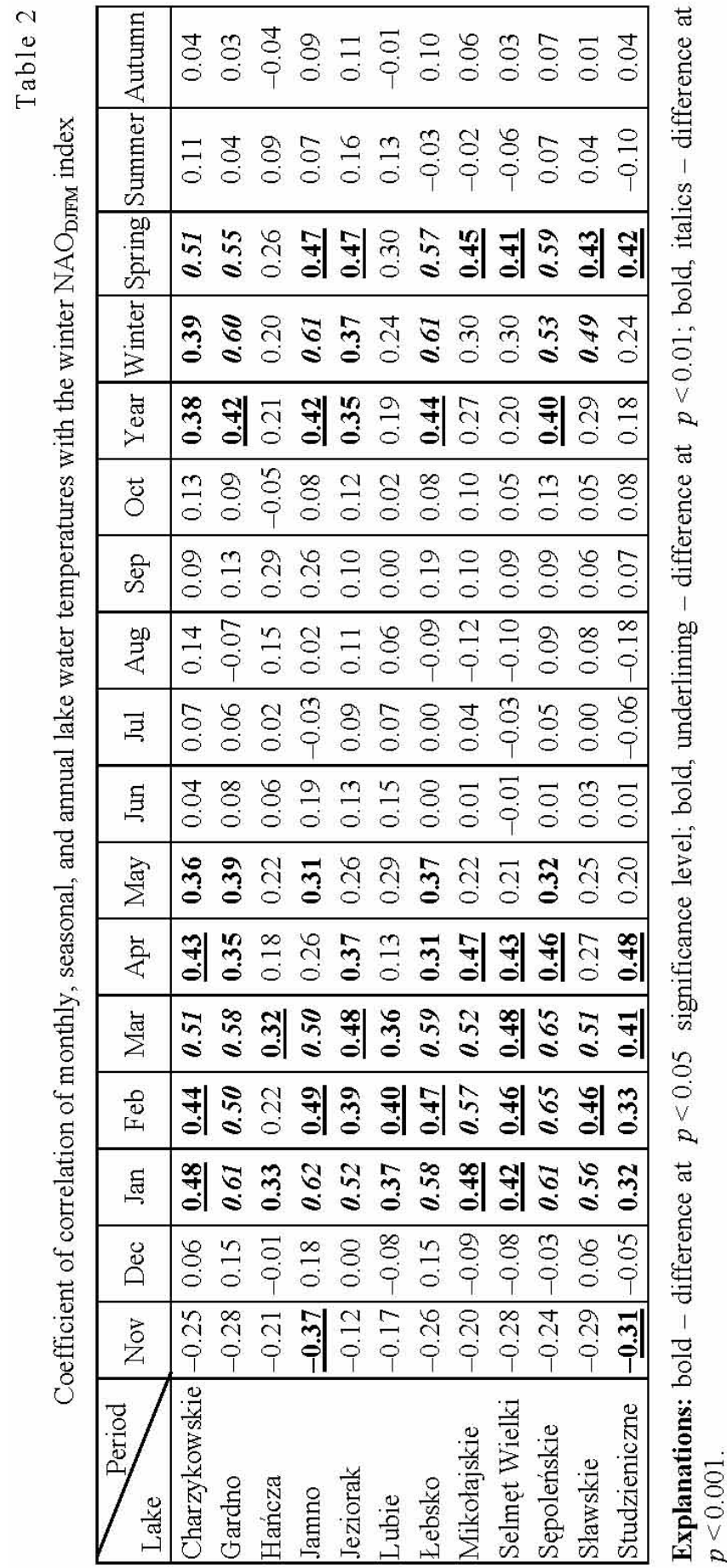


$\frac{1}{2}$

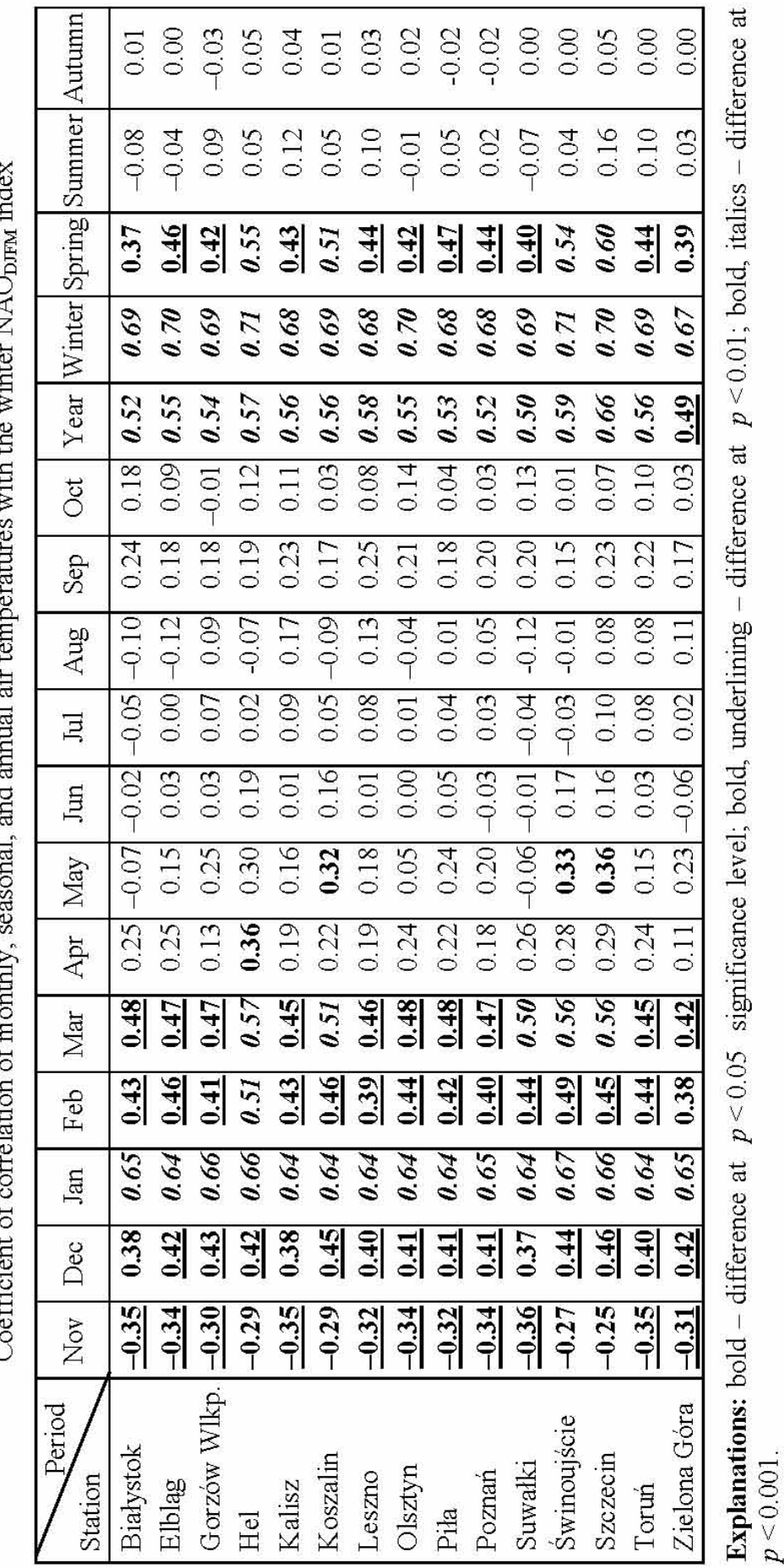




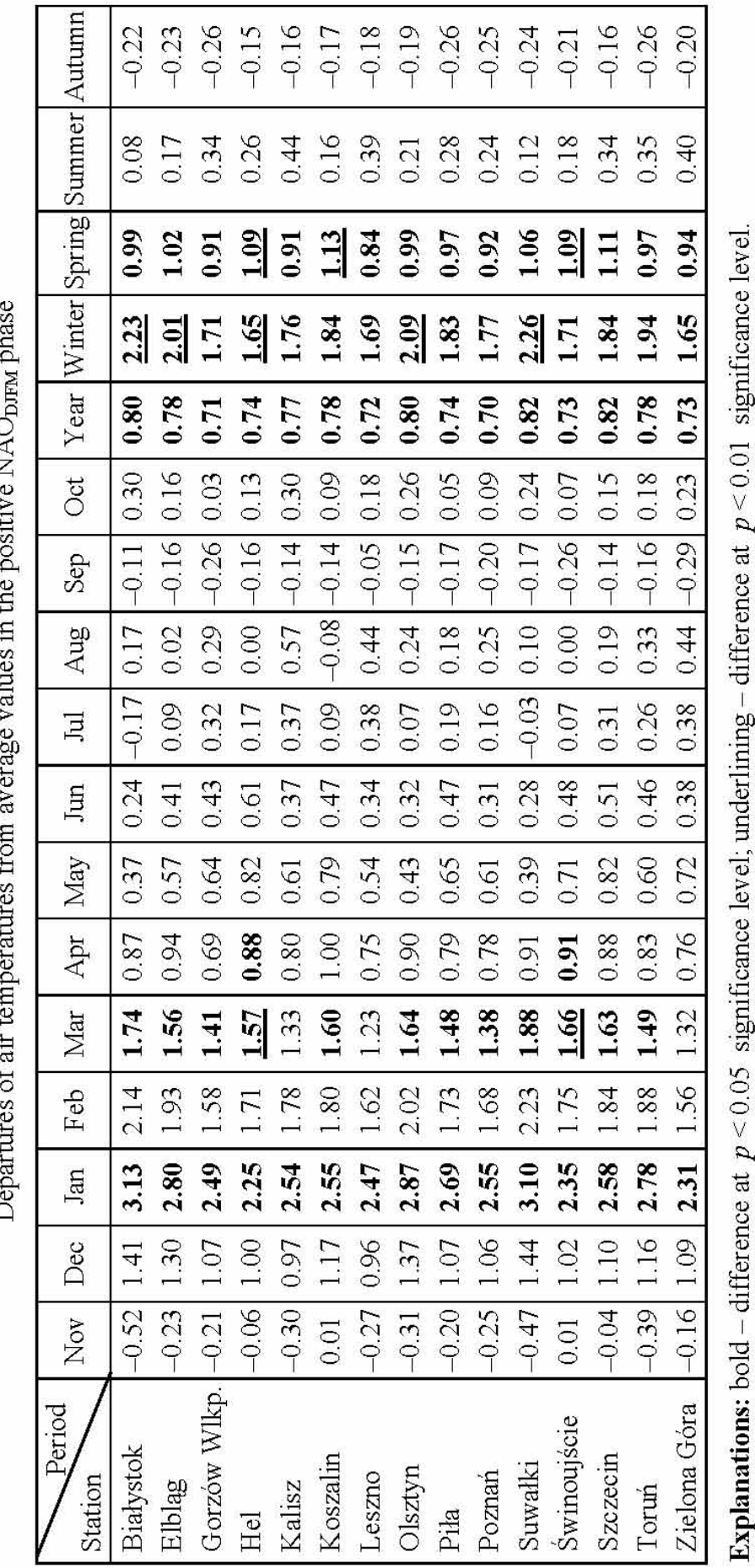


$\frac{n}{6}$

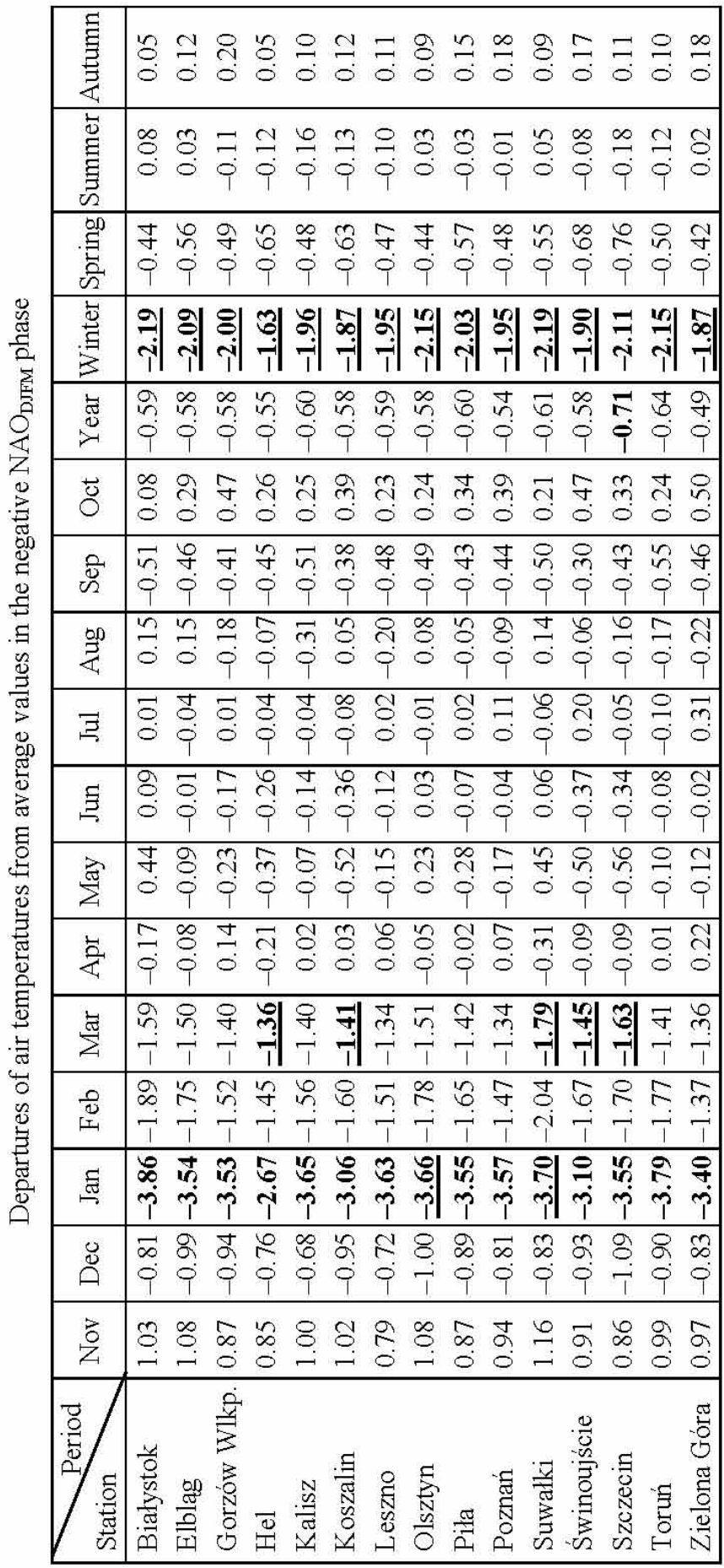


$\frac{6}{0}$

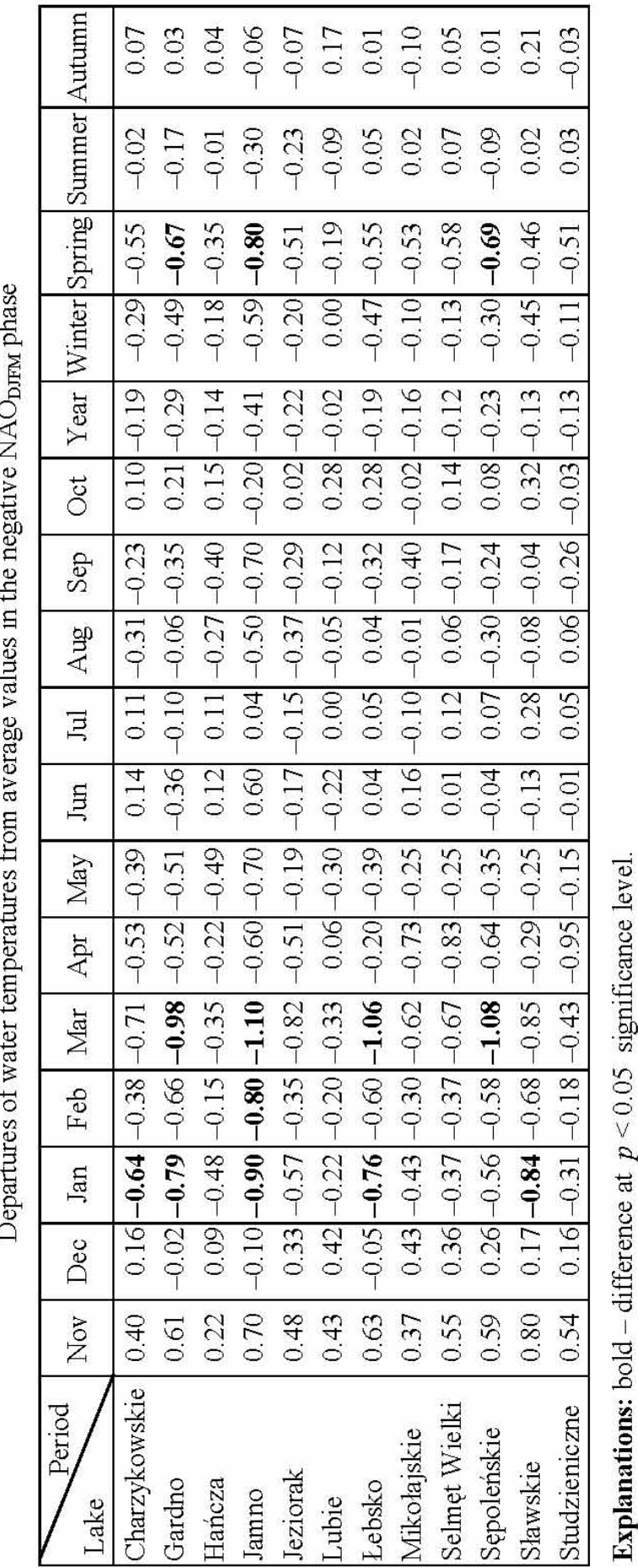


$\frac{0}{0}$

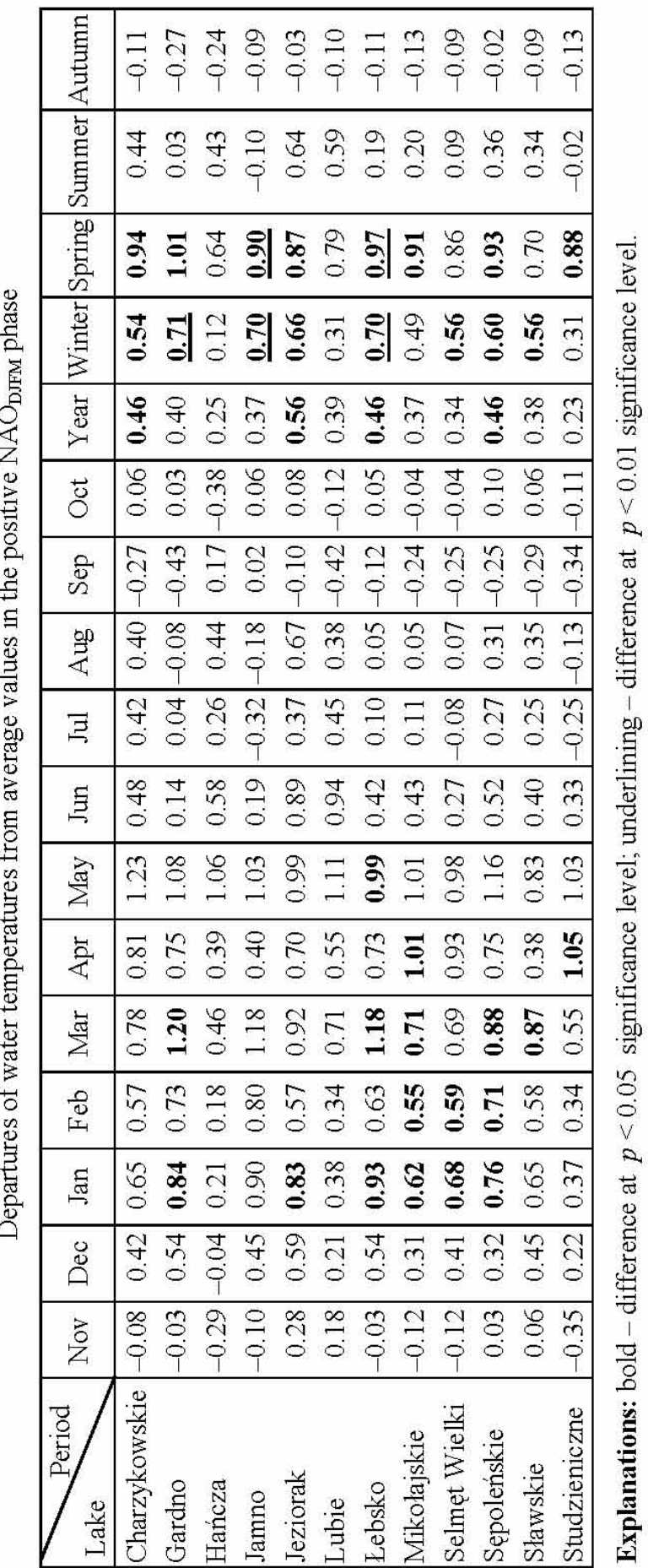



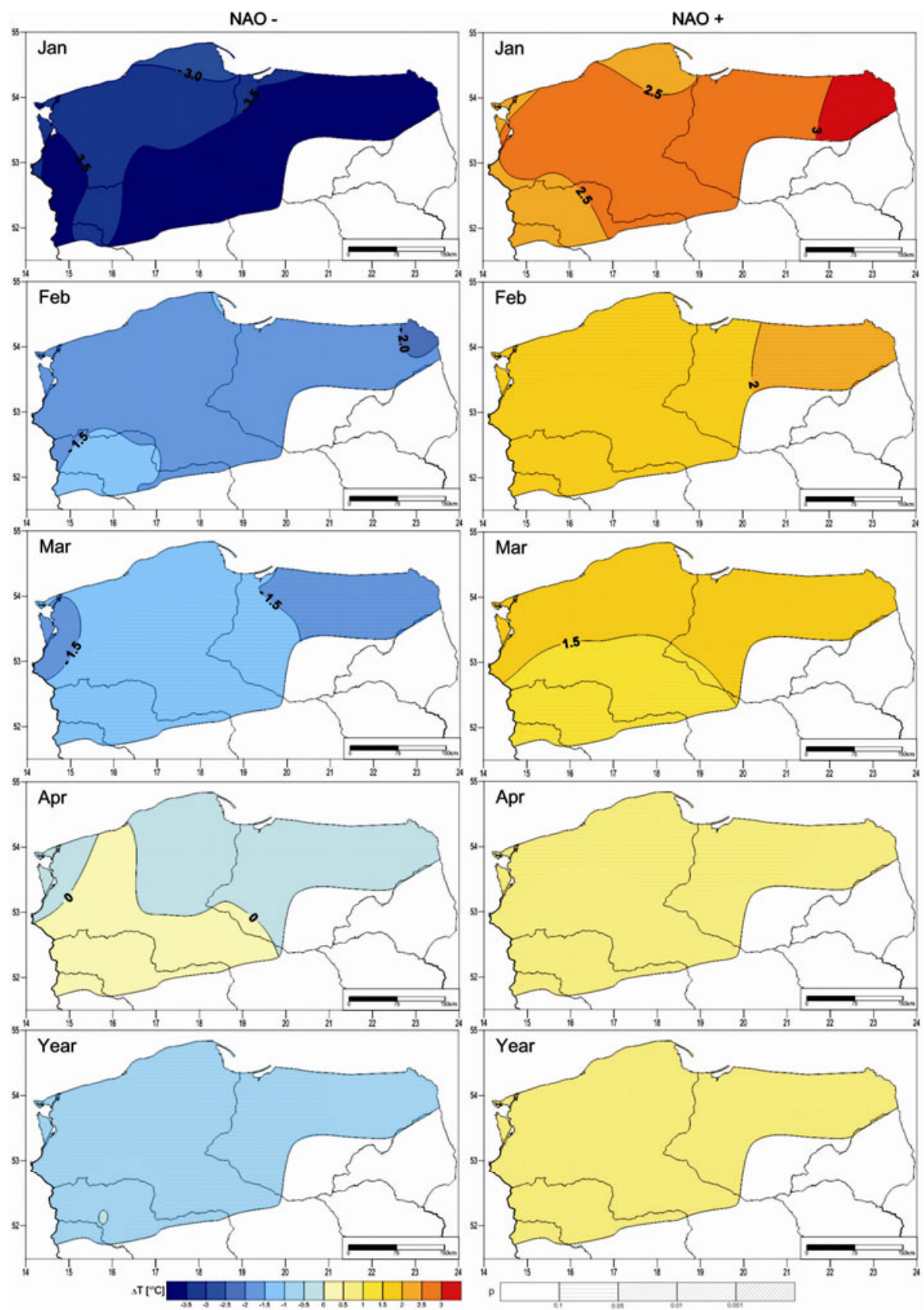

Fig. 2. Departures of selected monthly and annual air temperatures $(\Delta T)$ in the two $\mathrm{NAO}_{\text {DJFM }}$ phases from the 1971-2010 means, and their statistical significance $(p)$. 

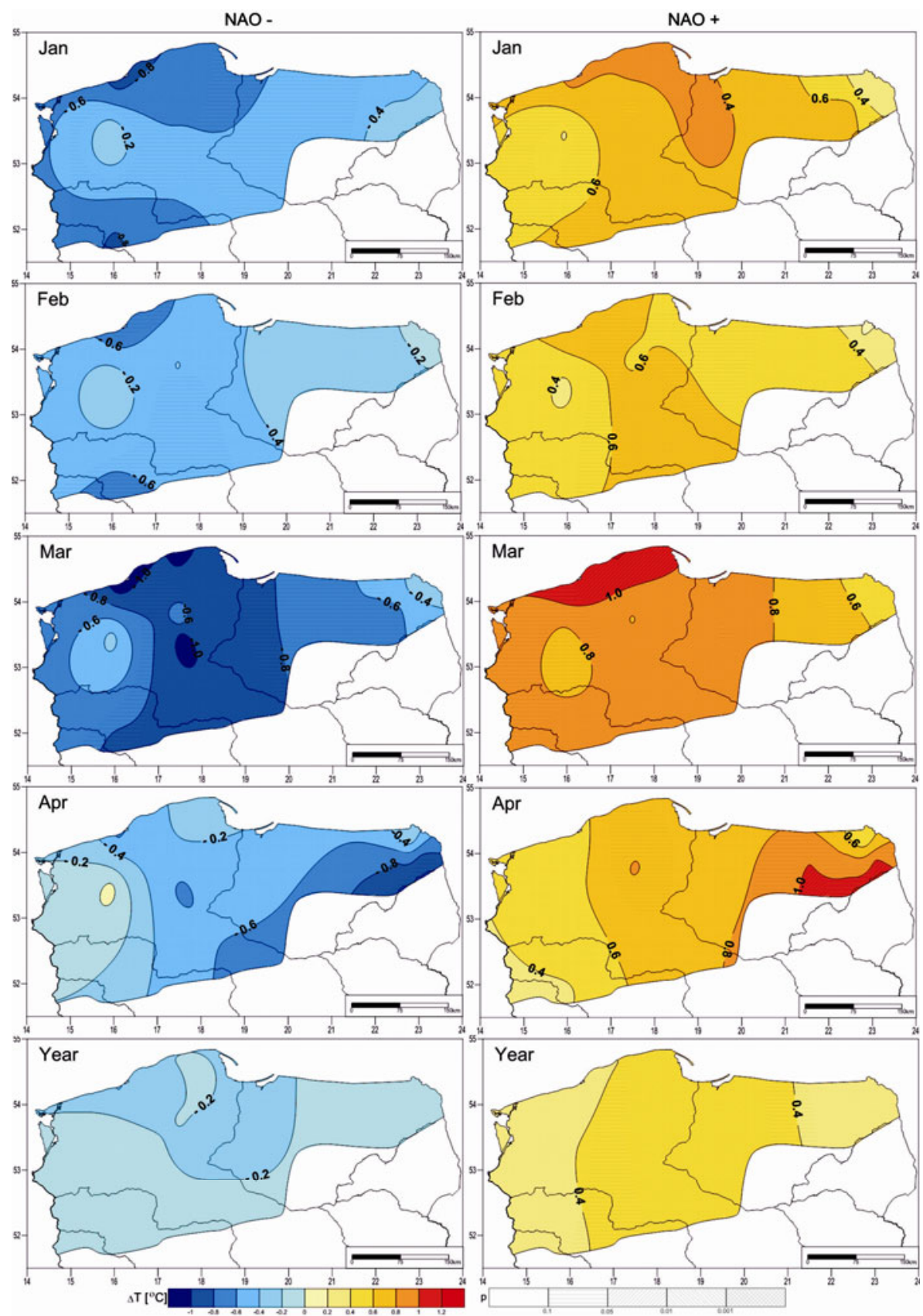

Fig. 3. Departures of selected monthly and annual temperatures of lake waters $(\Delta T)$ in the two $\mathrm{NAO}_{\text {DJFM }}$ phases from the 1971-2010 means, and their statistical significance $(p)$. 
(with the exception of Hańcza). Even wider differences in the water temperatures of all the lakes, in excess of $1{ }^{\circ} \mathrm{C}$, can be noted in May, but they are usually statistically insignificant, at $p>0.05$. In the positive $\mathrm{NAO}_{\text {DJFM }}$ phase there is a similar spatial pattern of departures from the average in lake water temperatures in the winter-spring season. Winter temperatures exceed then the average by more than $0.6^{\circ} \mathrm{C}$, and in spring by more than $0.8^{\circ} \mathrm{C}$, and the differences are statistically significant $(p<0.05)$. The intensity of the North Atlantic Oscillation in the winter season has no effect on the temperature of lake waters in the remaining seasons of the year, i.e., in summer and autumn. However, the elevated water temperatures in winter and spring cause annual temperatures of lake waters to be higher than average in this $\mathrm{NAO}_{\mathrm{DJFM}}$ phase, too. Also in the case of this variable the greatest increase in water temperature $\left(0.5^{\circ} \mathrm{C}\right)$ is recorded in the lakes located in the central part of the study area, and the observed differences are statistically significant $(p<0.05)$.

The situation is different in the negative NAO DJFM phase. The temperature of lake waters in the winter-spring season is markedly lower than average. In January the greatest drops in temperature amount to $0.8^{\circ} \mathrm{C}$, in February to $0.6^{\circ} \mathrm{C}$, and in March even to more than $1.0^{\circ} \mathrm{C}$. As in the case of temperature changes in the positive $\mathrm{NAO}_{\text {DJFM }}$ phase, spatial differences in the observed departures from the average show the greatest drop in water temperature to occur in lakes situated in the central and southern parts of the study area (Fig. 3). In the negative $\mathrm{NAO}_{\text {DJFM }}$ phase, water temperatures in winter, spring, and the entire year are lower than average by $0.4^{\circ} \mathrm{C}$, more than $0.6^{\circ} \mathrm{C}$, and $0.2^{\circ} \mathrm{C}$, respectively. However, the observed differences are statistically insignificant $(p>0.05)$.

\subsection{Effect of lake morphometry and location}

The causes of the observed changes in lake water temperatures in the different $\mathrm{NAO}_{\text {DJFM }}$ modes should be sought, for obvious reasons, in changes in air temperatures. Departures of air temperature from the average are even wider than of lake waters. In the positive $\mathrm{NAO}_{\text {DJFM }}$ phase, they can exceed the average by more than $3^{\circ} \mathrm{C}$ in January, more than $2^{\circ} \mathrm{C}$ in February, and $1.5^{\circ} \mathrm{C}$ in March. Worth noting are smaller spatial differences in the observed departures of air temperatures, with a characteristic increase to the east. In the negative $\mathrm{NAO}_{\text {DJFM }}$ phase, air temperatures are much lower than average: more than $3.5^{\circ} \mathrm{C}$ in January, $2^{\circ} \mathrm{C}$ in February, and $1.5^{\circ} \mathrm{C}$ in March.

As follows from a comparison of changes in lake water temperatures with those in air temperatures, they concern not only the magnitude of differences in water and air temperatures, but also their temporal and spatial variability. This is due to differences in the heat balance of the lakes, which depend on their morphometry and location. There is a marked lag in the response of water temperature to changes in air temperature, hence the greatest 
changes in water temperature can be observed later, from March to May. Besides, individual features of the lakes cause wider spatial differences in water temperature changes in the two $\mathrm{NAO}_{\text {DJFM }}$ phases.

To establish which bodies responded the strongest to air temperature, coefficients of the correlation between monthly, seasonal, and annual differences in air temperatures were calculated for the fifteen weather stations and the twelve lakes studied. Irrespective of the $\mathrm{NAO}_{\text {DJFM }}$ mode, the strongest connections were recorded for Lakes Gardno, Łebsko, and Jamno. Changes in their water temperature were very strongly correlated with those in air temperature recorded not only at the nearest stations, but also, though less distinctly, at the remaining stations $(p<0.001)$.

In turn, the weakest correlation links in the positive $\mathrm{NAO}_{\mathrm{DJFM}}$ phase were found for Lakes Hańcza and Lubie, and in the negative phase, for Lubie, Mikołajskie, Selmęt Wielki, and Studzieniczne. As a rule, for those lakes the coefficients of the correlation between changes in water temperature and those in air temperature were low at most of the weather stations under study. They also had the lowest coefficients of the correlation between the winter $\mathrm{NAO}_{\mathrm{DJFM}}$ index and the annual and winter water temperatures.

The reasons for the above unique features should be sought in their location and morphometric features. There are many works highlighting the connection between thermal characteristics of lakes and their local and individual features (Edmundson and Mazumder 2002, Nowlin et al. 2004, Houser 2006, Šporka et al. 2006, Wang et al. 2012, Novikmec et al. 2013). An analysis of the coefficients of the correlation between the morphometric parameters of the lakes (area, geographical latitude and longitude, mean depth, exposure, elevation a.s.1.) and changes in their temperatures in the two $\mathrm{NAO}_{\text {DJFM }}$ modes showed their mean depth to have the greatest effect on changes in the temperature of their waters. In the positive NAO $\mathrm{DJFM}_{\text {phase, }}$ there is a statistically significant dependence between the departures of lake water temperature from the average and the mean depth of a lake (Fig. 4). As
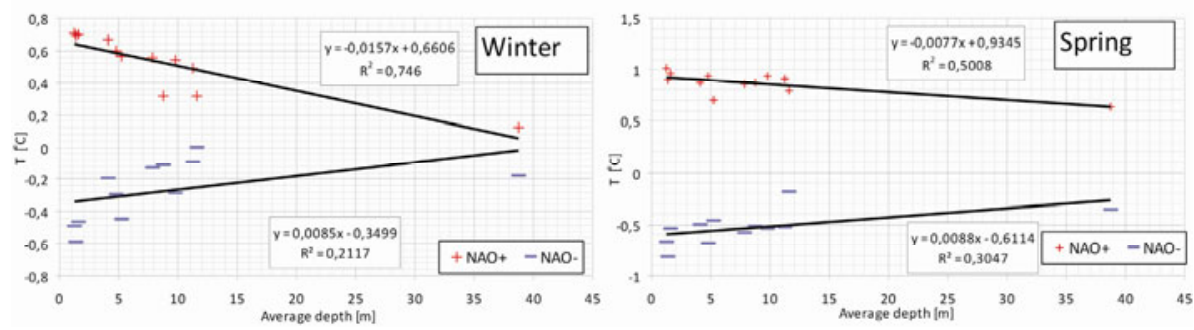

Fig. 4. Departures of the water temperature of the lakes from the average in the winter and spring seasons in the positive (NAO+) and the negative (NAO-) $\mathrm{NAO}_{\mathrm{DJFM}}$ phase depending on their mean depth. 
the mean depth increases, the observed differences in temperatures in winter $(r=-0.864, p<0.01)$ and spring $(r=-0.708, p<0.01)$ keep narrowing.

In the negative $\mathrm{NAO}_{\mathrm{DJFM}}$ phase, the coefficients of the correlation between the departures of temperatures from the average and the morphometric parameters of the lakes are lower and statistically less significant.

The most susceptible to changes in water temperature are polymictic lakes (Gardno, Łebsko, and Jamno), with small mean depths and water masses mixing many times during the year. All three lakes have specific hydrological systems, heavily dependent on local characteristics, as emphasised by Cieśliński and Major (2012). Even so, their direct connection with the Baltic Sea (inflows of marine waters with their different physicochemical properties) and other elements (contact of the shorelines with peatlands, considerable thicknesses of sediments) are not decisive factors in modifying the thermal characteristics of those lakes.

In turn, in the case of Hańcza and Lubie, the lack of a strong correlation between the temperature of their waters and air in the positive NAO ${ }_{\text {DJFM }}$ phase can be explained by their great mean depth - the greatest among all the water bodies under study. It should be stressed that Hańcza is the deepest lake in the entire Central European Lowland. Because of those features, both water bodies have a great ability to accumulate heat, as pointed out by, e.g., Choiński (2007), who established that large and deeper lakes emitted heat much longer than shallower ones. Besides, the great depths of the two bodies make possible their more substantial alimentation by groundwater, the temperature of which can differ from that of lake waters. The basins of Lubie and Hańcza penetrate into Quaternary water-bearing formations, which can be even up to $40 \mathrm{~m}$ thick. Groundwater alimentation affects the thermal characteristics of those lakes - its intensity can cause a change in the heat balance of a lake and affect the thickness of its ice cover (Choiński and Ptak 2012). Thus, both water bodies can be said to display a sort of thermal inertia with respect to atmospheric conditions.

\section{CONCLUSIONS}

The research has proved the North Atlantic Oscillation to have a big influence on the temperature of both, air and lake waters in the study area. The analysis of data from the fifteen weather stations confirmed the strong effect of its intensity on the mean annual temperature of air and those of the winter and spring seasons, the correlations observed being statistically significant (Table 3). In turn, the analysis of the temperatures of the twelve lakes under study showed the NAO to have a significant impact on the annual water temperature in six of them. Its influence was greater in winter (statistically 
significant relations were noted for seven lakes) and in spring (here the relationship was found for ten lakes, Table 2).

Air temperatures tended to depart from the mean values more considerably in a positive NAO phase. This was observed at all the stations, both in the case of annual mean temperatures and those of the winter and spring seasons (Table 4). In a negative NAO phase the greatest departures from the means occurred in winter (all stations, Table 5). As to the temperatures of water, in a negative NAO phase their departures from the means were significant in only three cases in spring (Table 6). In a positive NAO phase significant differences in annual temperatures were recorded in four of the lakes, and in the winter and spring seasons, in eight of them (Table 7).

Lake water temperatures in the winter and spring seasons are markedly higher than average in the positive $\mathrm{NAO}_{\text {DJFM }}$ phase, and lower in the negative phase; the observed differences can even reach $1.0^{\circ} \mathrm{C}$. Those changes in the temperature of lake waters in the two $\mathrm{NAO}_{\text {DJFM }}$ phases are caused by changes in air temperatures, which are even wider in those periods. Still, the spatial pattern of differences in air temperature changes, with their characteristic rise to the east, is different from that of lake water temperatures. The observed changes concern not only the magnitude of differences in water and air temperatures, but also their temporal and spatial variability. This follows from differences in the heat balance of the lakes, which depends on their morphometry and location. Water temperatures of some lakes do not show a close dependence on climatic conditions connected with NAO intensity. A weaker impact of the macro-scale climatic factors results from the location and morphometry of those lakes. As the conducted analysis has shown, an important parameter controlling the response of the thermal characteristics of lake waters to changes in air temperature is the mean depth of a lake. Lakes with the greatest mean depths, and hence the largest heat resources, are the most "resistant" to changes in air temperature, while those more sensitive to changes in thermal conditions are polymictic lakes characterised by the smallest mean depths.

The observed increase in lake water temperatures caused, among other things, by an intensive North Atlantic Oscillation can lead to a gradual transformation of lacustrine ecosystems. The transformation can affect both, their physico-chemical processes and phenomena as well as living conditions in a water environment different from those obtaining so far. This can lead to changes in the water-mass circulation pattern, in the trophic type of lakes, and in the species composition of their flora and fauna. In the future, an interesting issue to examine seems to be the effect of other macro-scale types of circulation (AO, ENSO) on the thermal characteristics of lakes in Poland, and in Europe. 


\section{References}

Bryś, K., and T. Bryś (2002), Effect of the North Atlantic Oscillation on changes in humidity, radiation, dynamic and evaporation conditions in Wrocław-Swojc in the years 1946-2000. In: A.A. Marsz and A. Styszyńska (eds), Oscylacja Pólnocnego Atlantyku i jej rola w kształtowaniu zmienności warunków klimatycznych $i$ hydrologicznych Polski, Wyd. Uczelniane Akademii Morskiej, Gdynia, 147-162 (in Polish).

Carleton, A.M. (1988), Meridional transport of eddy sensible heat in winters marked by extremes of the North Atlantic oscillation, 1948/49-1979/80, J. Climate 1, 2, 212-223, DOI: 10.1175/1520-0442(1988)001<0212:MTOESH $>2.0$. $\mathrm{CO} ; 2$.

Choiński, A. (2006), Catalogue of Polish Lakes, Wyd. Nauk. UAM, Poznań (in Polish).

Choiński, A. (2007), Physical Limnology of Poland, Wyd. Nauk. UAM, Poznań (in Polish).

Choiński, A., and M. Ptak (2012), Variation in the ice cover thickness on Lake Samołęskie as a result of underground water supply, Limnol. Rev. 12, 3, 133-138, DOI: 10.2478/v10194-012-0053-5.

Cieśliński, R., and M. Major (2012), Differences in the abiotic parameters of water in coastal lakes in the light of the EU water framework directive: An example of the Polish southern Baltic coast, Acta Geophys. 60, 4, 1159-1179, DOI: $10.2478 / \mathrm{s} 11600-012-0018-8$.

D'Odorico, P., J.C. Yoo, and S. Jaeger (2002), Changing seasons: An effect of the North Atlantic Oscillation? J. Climate 15, 4, 435-445, DOI: 10.1175/15200442(2002)015<0435:CSAEOT>2.0.CO;2.

Edmundson, J.A., and A. Mazumder (2002), Regional and hierarchical perspectives of thermal regimes in subarctic, Alaskan lakes, Freshwater Biol. 47, 1, 117, DOI: 10.1046/j.1365-2427.2002.00775.x.

Ewert, A. (1973), The issue of the thermal continentality of climate in Poland and Europe against the continentality of the globe, Prace Stud. Inst. Geogr. UW 211, Klimatol. 6, 17-27 (in Polish).

Falarz, M. (2007), Snow cover variability in Poland in relation to the macro- and mesoscale atmospheric circulation in the twentieth century, Int. J. Climatol. 27, 15, 2069-2081, DOI: 10.1002/joc.1505.

Gerten, D., and R. Adrian (2001), Differences in the persistency of the North Atlantic Oscillation signal among lakes, Limnol. Oceanogr. 46, 2, 448-455, DOI: 10.4319/1o.2001.46.2.0448.

Gerten, D., and R. Adrian (2002), Effects of climate warming, North Atlantic Oscillation and El Niño-Southern Oscillation on thermal conditions and plankton dynamics in northern hemispheric lakes (review), The Sci. World J. 2, 586606, DOI: 10.1100/tsw.2002.141. 
Girjatowicz, J.P. (2011), Effects of the North Atlantic Oscillation on water temperature in southern Baltic coastal lakes, Ann. Limnol. Int. J. Limnol. 47, 1, 7384, DOI: $10.1051 / \mathrm{limn} / 2010031$.

Houser, J.N. (2006), Water color affects the stratification, surface temperature, heat content, and mean epilimnetic irradiance of small lakes, Can. J. Fish. Aquat. Sci. 63, 11, 2447-2455, DOI: 10.1139/f06-131.

Hurrell, J.W. (1995), Decadal trends in the North Atlantic Oscillation: Regional temperatures and precipitation, Science 269, 5224, 676-679, DOI: 10.1126/ science.269.5224.676.

Livingstone, D.M. (1993), Temporal structure in the deep-water temperature of four Swiss lakes: A short-term climatic change indicator? Verh. Internat. Verein. Limnol. 25, 75-81.

Livingstone, D.M., and M.T. Dokulil (2001), Eighty years of spatially coherent Austrian lake surface temperatures and their relationship to regional air temperature and the North Atlantic Oscillation, Limnol. Oceanogr. 46, 5, 1220 1227, DOI: $10.4319 / 10.2001 .46 .5 .1220$.

Marsz, A., and A. Styszyńska (2001), North Atlantic Oscillation and Air Temperature in Poland, Wyższa Szkoła Morska, Gdynia, 107 pp. (in Polish).

Novikmec, M., M. Svitok, D. Kočický, F. Šporka, and P. Bitušík (2013), Surface water temperature and ice cover of Tatra Mountains lakes depend on altitude, topographic shading, and bathymetry, Arct. Antarct. Alp. Res. 45, 1, 77-87, DOI: 10.1657/1938-4246-45.1.77.

Nowlin, W.H., J.M. Davies, R.N. Nordin, and A. Mazumder (2004), Effects of water level fluctuation and short-term climate variation on thermal and stratification regimes of a British Columbia reservoir and lake, Lake Reserv. Manage. 20, 2, 91-109, DOI: 10.1080/07438140409354354.

Ottersen, G., B. Planque, A. Belgrano, E. Post, P.C. Reid, and N.C. Stenseth (2001), Ecological effects of the North Atlantic Oscillation, Oecologia 128, 1, 1-14, DOI: $10.1007 / \mathrm{s} 004420100655$.

Przybylak, R., G. Wójcik, and K. Marciniak (2003), Influence of the North Atlantic and Arctic Oscillations on the thermal conditions in the cold season in Poland from 16th to the 20th centuries, Prz. Geof. 48, 1-2, 61-74 (in Polish).

Rogers, J.C. (1997), North Atlantic storm track variability and its association to the North Atlantic Oscillation and climate variability of northern Europe, J. Climate 10, 7, 1635-1647, DOI: 10.1175/1520-0442(1997)010<1635: NASTVA $>2.0 . \mathrm{CO} ; 2$.

Skowron, R. (2011), The Differentation and the Changeability of Choin Elements of the Thermal Regime of Water in Lakes on Polish Lowland, Wyd. Nauk. UMK, Torun, 346 pp. (in Polish).

Straile, D., and R. Adrian (2000), The North Atlantic Oscillation and plankton dynamics in two European lakes - two variations on a general theme, Glob. Change Biol. 6, 6, 663-670, DOI: 10.1046/j.1365-2486.2000.00350.x. 
Straile, D., K. Jöhnk, and H. Rossknecht ( 2003), Complex effects of winter warming on the physicochemical characteristics of a deep lake, Limnol. Oceanogr. 48, 4, 1432-1438, DOI: 10.4319/1o.2003.48.4.1432.

Styszyńska, A. (2001), North Atlantic Oscillation and precipitation on the territory of Poland, Prace Stud. Geogr. 29, 232-241 (in Polish).

Šporka, F., D.M. Livingstone, E. Stuchlík, J. Turek, and J. Galas (2006), Water temperatures and ice cover in lakes of the Tatra Mountains, Biologia 61, 18, S77-S90, DOI: 10.2478/s11756-006-0121-x.

Trigo, R.M., T.J. Osborn, and J.M. Corte-Real (2002), The North Atlantic Oscillation influence on Europe: climate impacts and associated physical mechanisms, Climate Res. 20, 1, 9-17, DOI: 10.3354/cr020009.

Wang, S., X. Qian, B.P. Han, L.C. Luo, and D.P. Hamilton (2012), Effects of local climate and hydrological conditions on the thermal regime of a reservoir at Tropic of Cancer, in southern China, Water Res. 46, 8, 2591-2604, DOI: 10.1016/j.watres.2012.02.014.

Wibig, J. (2001), Impact of the Atmospheric Circulation on Spatial Distributions of Air Temperature and Precipitation Anomalies in Europe, Wyd. Uniw. Łódz., 208 pp. (in Polish).

Wrzesiński, D., M. Ptak, and A. Baczyńska (2013), Effect of the North Atlantic Oscillation on ice phenomena on selected lakes in Poland over the years 19612010, Quaest. Geogr. 32, 3, 119-128, DOI: 10.2478/quageo-2013-0020.

Received 15 March 2014

Received in revised form 26 August 2014

Accepted 27 August 2014 